\title{
Biodiversity And Population Dynamics of Dust Mites
}

\author{
Kiran Lata Damle ${ }^{1}$, Seema Gupta ${ }^{2}$, Mukesh Sharma ${ }^{1}$ \\ ${ }^{I}$ Govt. Digvijay College,Rajnandgaon.(C.G.) ; Jaipur Institute of Biotechnology, Maharaj Vinayak Global \\ University, Jaipur. India. \\ ${ }^{2}$ Dept. of Zoology. Govt. Science College, Raipur (C.G.). Pt. R.S.U. Raipur, India.
}

\begin{abstract}
Mites are living organisms having cosmopolitan distribution and have free to parasitic mode of life. They are microscopic and belong to the largest Arthropods. According to their habit and habitat they are of different types like plant mites, gall mites, animal mites, poultry mites etc. They dwell in dust accumulating in carpets, bedding, fabrics, furniture and poultry.They are negatively phototactic.Mites are allergens too causing allergies, eczema, asthma, rhinitia, bronchitis etc to human and animals. Humidity and temperature are the most important factors that regulate the dust mite population. Common house dust mite population can be influenced by housekeeping practices. They are killed by predators in nature and by direct exposure to sunrays. As house dust mites are widely distributed, a lot of work has been done on the seasonal dynamics and distribution. The maximum literature available in library, journals, books and internet sites have been cited and studied for the diversity of dust mites and tried to summarize here.
\end{abstract}

Keywords: Dust mites, cosmopolitan, allergens, factors, influence and diversity.

\section{Introduction}

Mites are the micro and macro living organisms, have cosmopolitan distribution, free to parasitic mode of life. Mites are among the oldest of all terrestrial animals with fossils known from the early Devonian, nearly 400 million years ago ${ }^{1}$ (Norton et al., 1988)[1]. They are found everywhere and eat flakes of skin in addition to other things.

1. Taxonomy \& Habitat: Mites are tiny structured creature, belonging to the largest phylum Arthropoda, and are the most diverse representatives. Mites belong to Class Arachnida, Subclass Acari, Order Acarina. Most of the mites are the members of the family pyroglyphidae (Colloff. 2007; 2009)[2]. Mites are distributed everywhere and have plasticity in habitat. Most of the mites are microscopic size. Many of the mites live freely in the soil or water (fresh or marine), but a large number of mites species live as parasites on plants, animals (invertebrate \& vertebrate), some are predators while others are beneficial symbionts (Holliday et al., 2000)[3]. About 48,200 species of mites have been described. A large number of mites are found in the dust of home, offices, hospitals and other human and animal environment. They live in bedding and carpets and feed on skin shed by person, mice and pets (Nayer et al. 1974)[4]. They live in our rugs, furniture, mattresses, and other areas where organic detritus and high level humidity is accumulated.

2. Types of mites: according to the habit and habitat mites are of different types. They are plant pest mite including spider mites (Bolland H. R. et al., 1997)[5], thread footed mites and gall mites (Yutaka Saito. 2009)[6]. etc.; animal mites such as demodex mites (family demodicidae) living in or near hair follicle, sarcoptic mange mite (family sarcoptidae) that burrow under the skin; insect mite (family tarsonemidae); dog and cat mite etc; poultry dust mites; house dust mites and storage mites. Some are very harmful to human and cause diseases such as clover mites, itch mites harvest mites etc. Kern (1921)[7] discovered Dermatophagoides pteronyssinus in house dust as allergen in U.S.A. 8 Miyamota et al. (1969)[8] found $D$. farinae as common floor dust mite. Prevalence of two most common species of Dermatophagoides, $d$. farinae and d. pteronyssinus (Hughes 1961)[9] established in the house dust samples of India. Dust mites are cosmopolitan in distribution accumulating in carpets, bedding, fabrics and furniture's. In the world 36 species of house dust mites have been reported, out of which 29 have been reported in India.

Dust mites are also present in poultry dust. Bird mites feed on bird's blood dwelling near bird's nest and poultry house. Mites are negatively photo tactic, the anterior-lateral regions of the body being sensitive to light (Murton and Madden. 1977)[10].

3. Morphology \& Life cycle: Mites are minute sac like animals without body division. They are small sized, microscopic with translucent bodies, measuring 420 micrometers in length and 250-320 microns in width, adult mites are creamy blue and rectangle or oval in shape. Mouth parts produce a head like structure bearing a pairs of chelicerae and a pair of padipalps. Four pair legs are found, Eyes and antenna are absent. The whole body bears long hairs and setae (Thompson et al. 1958)[11]. Dust mites are poikilothermic animals so the length of their life cycle varies with the temperature. Female lay eggs at the rate of 1-3 per day depending upon the environmental condition (Hart, 1998)[12]. The stages in the life cycle are the egg, a 
six legged larva protonymph, eight legged nymph stage tritonymph and adult male and females (Arlian, 1989)[13].

4. Mites and Allergy: about 10 million people suffer from different allergy type like allergies, eczema, asthma, rhinitia, bronchitis etc. In India Rao et al. (1973)[14] at Bhilai, 15 Nayar et al (1974)[15] and Krishnarao et al (1982)[16] at Bangalore, Tripathi and Parikh (1984)[17] at Bombay, Tilak and Jogdand (1989)[18] at Aurangabad have worked on house dust mite allergy. The allergens are some enzymatic proteins present in mite debris or skin faeces in the form of dry pellets which deposit on skin by dust mites which makes allergy or irritation on human skin; inhale of pellets mediate sensitization of bronchial hyper responsiveness causing bronchitis (Carlos et al. 2011)[19]; in the bed of asthmatic patients Dematophagoides mites were found in abundantly (Saha 1994)[20], and their serum contained significantly higher IgE concentrations (Sun and Lue 2000)[21]. Perennial allergic rhinitis is a common chronic disorder that results most frequently from sensitivity to house dust mites (Sheikh and Hurwitz. 2003)[22]. Mahesh et al. (2005)[23] suggested a possible association of house dust mite sensitivity with chronic urticaria. Poddar et al. (2006)[24] carried out a systematic survey on the prevalence of total mites and four common allergic mites in the city of Kolkata. Marina et al. (2007)[25] indicated that along with dermatophagoides, blomia tropicalis is also found common and abundant allergen responsible for asthma and rhinitis from house dust mite in some part of the world. Magnus Wickmam (1991)[26] and Levin (2004)[27] studied the house dust mite sensitization in children.

5. Factors regulating dust mite frequency: Environmental factors like temperature, rainfall and relative humidity are found to determine the indoor mite's population. Walters and Proctor, (1999)[28] found a significant association between the presence of mites and the relative humidity, any condition which help to maintain high humidity increases the house dust mite population. Live mites were seen only when the relative humidity had been above 50\% during the month of collection (Andrew et al. 1979)[29]. Relative humidity also affects the development and growth of the mite population (Zheltikova. 1985)[30]. Tilak and Jogdand (1989)[18] worked on the impact of environment on the occurrence of house dust mites in different localities of Aurangabad and reported highest percent contribution of house dust mite is recorded during rainy season in the month of September under congenial environmental conditions, when the temperature was around $25^{\circ} \mathrm{C}$ and range of humidity was between $75 \%$ and $85 \%$. The highest concentrations of house dust mites within homes are usually in areas of high use such as beds, furniture and carpeted floors in areas where humans shed skin (Korsgaard. J. 1998)[32]. Feeding rate and allergen production is directly influenced by the relative humidity; mites feed, multiply, and produce more faecal matter at higher relative humidity than at lower ones (Arlian, 1992[33]; Channa Basavanna, 1995)[34].

The house dust mites are extremely sensitive to minimal variations in microclimate (Cadman A. et al. 1998)[35], numbers of mites fluctuate according to season. In temperate climates, mite's density follows a seasonal cycle which corresponds to relative humidity with highest mite levels in summer and early fall seasons characterized by high humidity. Pyroglyphids were highest in summer and lowest in winter; glycyphagids were highest in autumn and lowest in spring Murrey And Zuk, 1979[36]; Chew et al, 1999[37]; and Chaudhary et al, 2011)[38].

6. Housekeeping practices \& Control: The population of house dust mites can be influenced by housekeeping practices. Regular vacuuming, replacing carpets, covering mattresses and pillows in plastic and lowering humidity can reduce mite population. The RCC type of buildings supports maximum dust mites population, followed by Assam type (semi- RCC) buildings, and the lowest count was observed in the wooden houses (Sharma et al. 2011)[39]. The concentration of house dust mites in the patient's dwellings was also associated with the age of the patients and increased with increasing number of persons in the households (Hallas and Korsgaard, 1997)[40].

Mites are killed by predators in nature. Effective management of mites is possible through better cleaning practices, proper waste diposal methods from dwelling and application of disodium octaborate tetrahydrate (DOT) (Codina et al, 2003)[41]. Other than this, herbs specially seeds of kranj, caster and neem is also utilized as extract in controlling these harmful dust mites (Khatri et al, 2011)[42].

\section{Dust mites diversity}

The seasonal distribution of different acaroids mite species may differ with the major limiting factors like temperature, humidity and eating habits. The determining species composition and diversity of mite community's in house ecosystem also differ. Comparing to the field and the forest, in human living area including house and working place, mites showed less bio-diversity. Here presenting list of work done on dust mite's diversity in different regions/ countries/states/cities related to the habit and habitat. We tried to cover maximum dominant group and families of acaroids species. (TABLE.) 


\section{Conclusion}

Mites are microscopic living organisms having cosmopolitan distribution, included in arthropods, having free to parasitic life on plants and animals. They are abundantly found in the dust of homes, offices, hospitals, poultry farms, etc. they live in bedding, carpets, our rugs, furniture, mattresses. They are versatile from plants to animals. Some mites are harmful to human and cause allergy diseases such as eczema, skin rashes, wheezing, coughing, fatigue, headache, asthma, rhinitis (common chronic disorder), and bronchitis in adults, women and children. The frequency of dust mites are regulated by the environmental factors like temperature, rainfall and relative humidity. Under these congenial environmental conditions the dust mite population increases. They are extremely sensitive to minimal variations in microclimate fluctuating according to season following a seasonal cycle. Indeed the population of house dust mites can be influenced by the housekeeping practices like regular vacuuming, replacing carpets, covering mattresses and pillows by plastic, proper waste disposal methods from dwellings, and lowering humidity. Dust Mites are killed by the predators in nature and when exposed to direct sunrays. By applying chemicals like disodium octaborate terahydrate (DOT), Lindane, malathion, DDT, locally available seeds like kranj, castor and neem. Dust mites are seasonal dynamic and widely distributed in human habitat and work environment and produce very harmful allergens. Though small, dust mites have a huge impact on society. A large percentage of the population has been affected by them; hence multiple industries have developed to produce wide varieties of products for cleaning, dust protection, treatment and reduction of dust mites and to reduce the number of people that suffer from symptoms associated with dust mites. Farther studies and researches on dust mites may be the field of interest for forth coming scholars.

\section{Reference}

[1] Norton, R.A. (1988). Phylogenetic perspectives on genetic systems and reproductive modes of mites, New York: Chapman and Hall: 8-99.

[2] Colloff, M. J. (2007, 2009): Taxonomy and identification of dust mites. CSIRO: 600

[3] Holliday R. B., Oconnor B. M. and Baker A. S. (2000): "Global Diversity of Mites". Nature and human society: the quest for a sustainable world : proceedings of the 1997 Forum on Biodiversity.

[4] Nayer, E., Lal, M. and Dasgupta, A. (1974): The prevalence of mite Dermatophagoides pteronyssinus and its association with house dust Allergy. Indian J. Med. Res., 62: 11-14.

[5] Bolland H. R., Jean Gutierrez \& Carlos Flechtmann H. W. (1997). "Introduction". World Catalogue of the Spider Mite Family (Acari: Tetranychidae). Brill Publishers. pp. 1-3. ISBN 978-90-04-11087-8.

[6] Yutaka Saito (2009). "Plant mites". Plant Mites and Sociality: Diversity and Evolution. Springer. pp. 5-38. doi:10.1007/978-4-43199456-5_2. ISBN 978-4-431-99455-8.

[7] Kern. 1921. Dust sensitization in bronchial asthma. K. Clin.N.America, 5 : 751-758.

[8] Miyamoto, T.S., Oshima, K., Mizuno, M., Sasa, T. and Ishizaki (1968): Allergic identity between the common floor mites (D.farinae) and house dust as a causative antigen in bronchial asthma. J. Allergy, $\mathbf{4 2}: 14$

[9] Hughes, A.M. 1961. The mites of stored food. Her Majesty's stationary office, London, 287.

[10] Murton, J. J. and Madden, J. L. (1977): Observation on the biology, behavior and ecology of the house dust mite Dermetophagoides pteronyssinus (Trouessart) (Acarina: pyroglyphidae) in Tasmania. Australian Journal of Entomology, 16 (3): $281-287$.

[11] Thompson 1958

[12] Hart, B.J. (1998): Life cycle and reproduction of house dust mite: environment factors influencing mite population. Allergy, 53: 1317.

[13] Arlian, L.G. 1989. Biology and ecology of house dust mites Dermatophagoides sp.and Euroglyphus sp. J. Immunol. Allergy Clin. Am, $9: 339-356$

[14] Rao, Khuddus, N.S. and ChannaBasavanna, G.P. (1973) Pyroglyphid mites in man and his surroundings. Current Science, 42:33.

[15] Nayer, E., Lal, M. and Dasgupta, A. (1974): The prevalence of mite Dermatophagoides pteronyssinus and its association with house dust Allergy. Indian J. Med. Res., 62: 11-14.

[16] Krishna Rao, Khuddus, N.S. and ChannaBasavanna, G.P. (1982). House Dust Mites from India. Indian J. Acar., 5: 85-94.

[17] Tripathi T.M. and Parikh K.M. (1984). Occurrence of house dust mites in Bombay. Aspects of Allergy and applied immunology. 4: 58-80.

[18] Tilak, S.T. and Jogdand, S.B. (1989): Impact of environment on the incidence of house dust mites. Ind, J. Aerobiol., 2: 35-38.

[19] Carlos, A. G. P., Clode, M.H.M., Trindade, J.C. and Romas, J.M.C. (2011): Hypersensitivity of house dust and mites. Allergy, 2 (20): 1373-1380

[20] Saha, G.K. (1994): Relationship between Dermatophagoides mite density and specific immune response in asthmatic patients. Ann Allergy, 73 (5): 429-433.

[21] Sun, H.L. and Lue, K.H. (2000): Household distribution of house dust mite in central Taiwan. Journal of Microbiology, Immunology, and Infection, 33(4): 233-236.

[22] Sheikh Aziz and Hurwitz Brian. (2003). House dust mite avoidance measures for perennial allergic rhinitis: a systematic review of efficacy. British Journal of General Practice. 53: 318-322.

[23] Mahesh, P. A., Kushalappa, P. A., Holla A. and Vedanthan, P.K. (2005): House dust mites sensitivity is a factor in Chronic Urticaria. Studies, 71: 99-101.

[24] Poddar, S., Gupta, S. and Saha G. K. (2006): Seasonal prevalence of allergenic mites in the city of Kolkata Metropolis, India. Aerobiologia, 25(1): 39-47.

[25] Marina, A., Santana Raj, A.S., Tan, S.N. and Ho, T.N. (2007): Scanning electron micrographs of Blomia tropicalis (Ascaris: Astigmata: Echimyopodidae, a common house dust mite in Malaysia. Tropical Biomedicine, 24(2): 29-37.

[26] Magnus Wickman, S.Lennart Nordvall, MD., Göran Pershagen, MD., Bente Schwartz and Jan Sundell. (1991). House dust mite sensitization in children and residential characteristics in a temperate region, Journal of Allergy and Clinical Immunology. Volume 88, Issue 1: 89-95. 
[27] Levin, M. (2004): House dust mites- what is the evidence for promoting reduction in exposure? Current Allergy \& Clinical Immunology, 17(3):116-120.

[28] Walter (1999)

[29] Andrew B., Murrey M.B., F.R.C.P. and Peter Zuk. (1979). The seasonal variation in a population of house dust mites in a North American city. J. Allergy Clin. Immunol. 64(4): 266-269.

[30] Zheltikova, T.M., Petrova-Nikitina, A.D., Kanchurin, A.K., Verzhets, V.M. and Muzyleva, I.L. (1985): Mites in house dust and human allergies, (2):12-30.

[31] Korsgaard, J. (1998): Epidemiology of house-dust mites. Allergy, 53: 36-40.

[32] Arlian, L. G. (1992): Water balance and humidity requirements of house dust mites. Experimental \& Applied Acarology, 16(1-2): 15-35.

[33] Channabasavanna, G. P. (1995): Current status of research on dust mites in India. Current status of Research, 129-142.

[34] Cadman, A., Prescott, R. and Potter, P C. (1998): Year- round house dust mite levels on the Highveld. J. Air. Med., 88 (5): 15801582 .

[35] Murray, A.B. and Zuk, P. (1979): The seasonal variation in a population of house dust mites in a North American city. J Allergy Clin. Immunol., 64(4): 266-269.

[36] Chew, G.L., Higgins, K.M., Gold, D. R., Muilenberg, M. L. and Burge, H. A. (1999): Monthly measurements of indoor allergens and the influence of housing type in a northeastern US city. Allergy, 54(10): 1058-1066.

[37] Chaudhury, S., Roy, I., Poddar, S., Gupta, S.K., and Saha, G.K. (2005): Diversity of synanthropic mites in Kolkata metropolis, India. Records of Zoological survey of India, 104(314): 151-159.

[38] Sharma, D., Dutta, B.K. and Singh, A.B. (2011): Dust Mites population in Indoor Houses of suspected Allergic Patients of South Assam, India. Pathology \& Microbiology, 54(1): 214-215.

[39] Hallas, T.E. and Korsgaard, J. (1997): Systematic variations in the appearance of house-dust mites Dermatophagoides sp., house mites Glycyphagus domesticus and of Tarsonemus sp. in dust samples from dwellings. Rev. Esp. Alergol. Immunol. Clín., Junio., 12 (4): 173-177. JULY 1986 797) 23-29.

[40] Codina, R., Lockey, R.F., Diwadkar, R., Mobly, L.L. and Godfrey, S. (2003): Disodium octaborate tetrahydrate (DOT) application and vacuum cleaning, a combined strategy to control house dust mites. Allergy, 58(4): 318-324.

[41] Khatri, K., Lodha, N. and Kaushik, V. (2011): Bioefficacy of herbal extracts in controlling house dust mites. J. Human Ecol., 34(1): 41-48.

[42] Milhim D. Alani, Niels Haarlov. (1972) The House-Dust Mite: A Possible Source of Allergen in the Environment of Patients with Atopic Dermatitis. Journal Of The National Medical Association. Vol. 64, No. 4: 304-358.

[43] Rasa, A.E. and Flechtmann, C.H.W. (1979): Mites in house dust from brazil. International Journal of Acarology, 5(3): $195-198$.

[44] Valandikar S.C. and Channa Basavanna G.P. (1987). Some faunistic studies on House Dust Mites in Karnataka. Man, Mites and Environment; 1: 111-118.

[45] Modak, A., Saha, G.K., Tondon, N. \& Gupta S.K. (1990): Dust mite fauna in houses of bronchial asthma patients - A comparative study of three zones of West Bengal (India). Endomon., 16 (2):115-120.

[46] Denegri, G.M. and Alzuel, A.B. (1992): Seasonal variation of oribatid mite (Acarina) populations and their relationship to sheep cestodiasis in Argentina. Veterinary Parasitology, 42(1-2):161- 167.

[47] Berry, R. E. (1998): Insects and mites of economic importance in the Northwest. $2^{\text {nd }}$ Ed. 211.

[48] Lakshmi, R. and Haq, M.A. (1999): Survey on dust mites of Calicut University campus. J. Acarol., 15 (1\&2): $55-63$.

[49] Putatunda, B.N., Mathur, S. and Mathur, R.B. (1999): Mites associated with some stored food products in Haryana. J. Acrol., 15(1-2): 64-67.

[50] Insung, A. (2002): Species diversity and biology of house mites in western Thong Pha Phum Kanchanaburi 6t ${ }^{\mathrm{h}}$ BRT. Annual Conference, Nakhon Si Thammarat (Thailand), 9-12.

[51] Chirico, J. (2003): The poultry red mite, Dermanyssus gallinae, a potential vector of Erysipelothrix rhusiopathiae causing erysipelos in hens. Med Vet Entomol. 17 (2): 232-234.

[52] Soleiman, M. and Rafinejad, J. (2008): House Dust Mite contamination in hotels and inns in Bandar Abbas, South of Iran. Iranian Journal of Environmental Health, 5(3): 207-210.

[53] Mohammad Yassin K.; Zakia, E. Ashmawy and Hasanin A. (2009). Study the quality of school environment as new habitat for allergenc mites in Cairo, Egypt. Acad. J. Biology Sci., 1: 103- 116.

[54] Douglas, G., Bradley, M., Hope, E. and Roy T Furumizo. (2010): Subtropical Acarian profile by topography, seasons and change of house furnishings: 80's blueprint to the future. Hawaii medical journal, 69 (4): 89-92.

[55] Sulaiman, A. and Nasser, A.L. (2011): Quantitative survey of stored products mites infesting wheat flour in Jeddah Governorate. Journal of Entomology and Nematology, $3(6): 78-84$.

[56] Banda, Z. (2011): Ectoparasites of indigenous Malawi chickens. Australian Journal of Basic and Applied Sciences, 5 (6): $1454-1460$

[57] Dautartiene, A. (2001): Seasonal changes in house dust mites. Ekologija, 2: 3-7.

Table: List of some work on Dust mites diversity

\begin{tabular}{|c|c|c|c|c|c|}
\hline Sl.N & $\begin{array}{l}\text { Region (Country/ } \\
\text { state/ City) }\end{array}$ & Habitat & Dominant group/Families & Dominant genera/ species & Reference \\
\hline 1. & $\begin{array}{l}\text { Copenhagen, } \\
\text { Denmark }\end{array}$ & $\begin{array}{l}\text { Residences of patients } \\
\text { with atopic diseases }\end{array}$ & $\begin{array}{l}\text { Pyroglyphidae, } \\
\text { Glycyphagidae } \\
\text { Cheyletidae }\end{array}$ & $\begin{array}{l}\text { Dermatophagoides } \\
\text { pteronyssinus, D. farinae, } \\
\text { Euroglyphus maynei. } \\
\text { Acoropsisdocta,Berlese, } \\
\text { Cheyletuseruditus,Schrank, } \\
\text { Cheyletus trouessarti } \\
\text { Oudemanns, } \\
\text { AcarussiroL.,Glycyphagus } \\
\text { privatus Oudemans }\end{array}$ & $\begin{array}{l}\text { Milhim et al., } \\
1972 \text { [43] }\end{array}$ \\
\hline 2. & Brazil. & House dust & $\begin{array}{l}22 \text { sps. } \\
\text { Glycyphagidae, } \\
\text { Pyroglyphidae, Cheyletidae, } \\
\text { Acaridae, } \\
\text { Tydeidae, Chortoglyphidae, } \\
\text { Raphignathidae, Ascidae, }\end{array}$ & $\begin{array}{l}\text { Dermatophagoides } \\
\text { pteronyssinus, } \\
\text { Dermatophagoidesfarinae, } \\
\text { Cheyletus eruditus, } \\
\text { Glycyphagu sp. }\end{array}$ & $\begin{array}{l}\text { Rasa and } \\
\text { Flechtman, } \\
1979 \text { [44] }\end{array}$ \\
\hline
\end{tabular}


Biodiversity And Population Dynamics Of Dust Mites

\begin{tabular}{|c|c|c|c|c|c|}
\hline & & & Oribatei & & \\
\hline 3 & Karnataka & House dust & 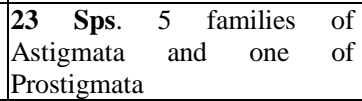 & Pyroglyphids & $\begin{array}{l}\text { Krishna Rao et } \\
\text { al., } 1981\end{array}$ \\
\hline 4 & $\begin{array}{l}\text { India Lucknow, } \\
\text { Darjeeling, Shilong } \\
\text { andCherrapunji, } \\
\text { Dibugarh, Jammu } \\
\text { \& Kashmir and } \\
\text { Delhi. }\end{array}$ & $\begin{array}{l}\text { Human houses (Healthy } \\
\text { \& Patient) }\end{array}$ & $\begin{array}{l}\text { 16 sps. } \\
\text { Acaridae (7 } \\
\text { Chortoglyphidae } \quad \text { (1-species), } \\
\text { Glycyphagidae (7 } \text { species) and } \\
\text { Labidophoridae (1 } \text { species) }\end{array}$ & $\begin{array}{l}\text { Dermatophagoides } \\
\text { pteronyssinus, D. farina, }\end{array}$ & $\begin{array}{l}\text { Rishi Ram et al. } \\
(1983)\end{array}$ \\
\hline 5 & Bombay & $\begin{array}{l}\text { Human houses (Healthy } \\
\& \text { Patient with bronchial } \\
\text { asthma) }\end{array}$ & Pyroglyphidae, & $\begin{array}{l}\text { D. farina } \\
\text { D. pteronyssinus }\end{array}$ & $\begin{array}{l}\text { Tripathi and } \\
\text { Parikh } \\
(1984)[17]\end{array}$ \\
\hline 6 & Karnataka & $\begin{array}{l}\text { Human and animal } \\
\text { houses }\end{array}$ & $\begin{array}{l}11 \text { species under } 8 \text { genera } \\
\text { which belong to } 6 \text { families. } \\
\text { Pyroglyphidae, }\end{array}$ & $\begin{array}{l}\text { D. pteronyssinus, D. farinae, } \\
\text { E. maynei, } \\
\text { A. griffutsi, D. gallinae , T. } \\
\text { longior, } \\
\text { T. rutrescentiae, C. berlesei, } \\
\text { B. tropicalis, } \\
\text { S. nesbitti. }\end{array}$ & $\begin{array}{l}\text { Valandikar and } \\
\text { Basavanna } \\
(1987)[45]\end{array}$ \\
\hline 7 & $\begin{array}{l}\text { Cool hilly region of } \\
\text { Tamil Nadu }\end{array}$ & $\begin{array}{l}\text { Brood chamber of Apis } \\
\text { Cerana. }\end{array}$ & varroaidae & $\begin{array}{l}\text { Dermatophagoides } \\
\text { pteronyssinus and D. } \\
\text { farinae, }\end{array}$ & $\begin{array}{l}\text { Soundararanjan } \\
\text { et al. } 1987 \text { [45] }\end{array}$ \\
\hline 8 & $\begin{array}{l}\text { Threedistricts of } \\
\text { WestBengal(24 } \\
\text { Parganas, } \\
\text { Barddhaman and } \\
\text { Calcatta }\end{array}$ & $\begin{array}{lrr}\text { Bed \& } & \text { Bed } & \text { room of } \\
\text { patients } & \text { of } & \text { asthma } \\
\text { diseases } & & \end{array}$ & Pyroglyphidae, & $\begin{array}{l}\text { Dermatophagoides } \\
\text { pteronyssinus and D. D. } \\
\text { farinae, Hirstia domicola. }\end{array}$ & $\begin{array}{l}\text { Modak et al. } \\
1991[46]\end{array}$ \\
\hline 9 & Paun, argentina. & Soil sample & Orbatid & 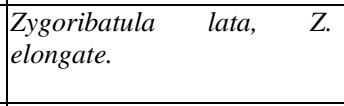 & \begin{tabular}{|lr} 
Denegri & and \\
alzuel, & 1992 \\
{$[47]$} & \\
\end{tabular} \\
\hline 10 & Northwest & $\begin{array}{l}\text { Injurios plant feeding } \\
\text { mites. }\end{array}$ & $\begin{array}{l}\text { Metaseiulus, ambltseius, } \\
\text { stigmaeidae }\end{array}$ & $\begin{array}{l}\text { Predator } r \text { mites- } \\
\text { Typhlodromus occdentallis, } \\
\text { and Neoseiulus fallacies, } \\
\text { Zezelli mali. }\end{array}$ & Berry 1998 [48] \\
\hline 11 & Kearla & Office, Hotels, Houses & $\begin{array}{l}\text { Pyroglyphidae, } \\
\text { Glycyphagidae } \\
\text { Acaridae }\end{array}$ & $\begin{array}{l}\text { Dermatophagoides } \\
\text { pteronyssinus, } \quad \text { Blomia } \\
\text { tropicalis, Malayaglyphus, } \\
\text { Rizoglyphus, Caloglyphus, } \\
\text { Austroglyphus, Glycyphagus }\end{array}$ & $\begin{array}{l}\text { Laxmi and Haq, } \\
1999 \text { [49] }\end{array}$ \\
\hline 12 & Haryana Punjab & Stored food products & Pyroglyphidae, Cheyletidae & $\begin{array}{l}\text { Chyletus malaccenus, } D . \\
\text { pteronyssinus, }\end{array}$ & $\begin{array}{l}\text { Putatunda et al., } \\
1999[50]\end{array}$ \\
\hline 13 & $\begin{array}{l}\text { Western Thong Pha } \\
\text { Phum, Kanchana- } \\
\text { buri }\end{array}$ & House mites & Pyroglyphidae Cheyletidae & $\begin{array}{l}\text { Dermatophagoides } \\
\text { pteronyssinus, Cheyletus sp. }\end{array}$ & $\begin{array}{l}\text { Insung } \\
(2002)[51]\end{array}$ \\
\hline 14 & Description & $\begin{array}{l}\text { Bacterial desease in } \\
\text { domestic fowl. }\end{array}$ & Poultry red mite & Dermanyssus gallinae, & Chirici, 2003 \\
\hline 15 & Iran. & Dust from hotels \& Inn & Pyroglyphidae, Cheyletidae & $\begin{array}{l}\text { D. pteronyssinus, Chyletus } \\
\text { melaccerisis }\end{array}$ & $\begin{array}{l}\text { Soleiman M } \\
\text { and Rafinejad J } \\
(2008)[53]\end{array}$ \\
\hline 16 & Egypt. & School & $\begin{array}{ll}\text { Pyroglyphidae } & \text { Cheyletidae } \\
\text { Dermanyssidae } & \end{array}$ & $\begin{array}{l}\text { Dermatophagoides } \\
\text { pteronyssinus, D. farina, } \\
\text { Cheyletus malccensis and } \\
\text { Dermanyssus sp. }\end{array}$ & $\begin{array}{l}\text { Mohammad et } \\
\text { al. }(2009)[54] .\end{array}$ \\
\hline 17 & Hawaii & Human houses & Pyroglyphidae, & $\begin{array}{l}\text { Dermatophagoides } \\
\text { pteronyssinus, }\end{array}$ & \begin{tabular}{|l} 
Douglas et al, \\
$2010[55]$
\end{tabular} \\
\hline 18 & Jeddah governorate & $\begin{array}{l}\text { Wheat floor, bakeries, } \\
\text { mills and departmental } \\
\text { stores. }\end{array}$ & $\begin{array}{l}\text { Pyroglyphidae, } \\
\text { Acarophenacidae, Chyletidae, } \\
\text { Acaridae }\end{array}$ & $\begin{array}{l}\text { Dermatophagoides farinae, } \\
\begin{array}{l}\text { Acarophenax tribolii, } \\
\text { Chyletus malaccenus, } \\
\text { Blattisocius tarsalis and } \\
\text { Blattisocius keogani }\end{array}\end{array}$ & $\begin{array}{l}\text { Sulaiman A. } \\
\text { and A.L. Nasser } \\
(2011)[56]\end{array}$ \\
\hline 19 & Malawi & Local chicken & Pyroglyphidae, & $\begin{array}{l}\text { Dermatophagoides gallinae, } \\
\text { cnemidocoptes mutans }\end{array}$ & \begin{tabular}{|l} 
Banda, \\
$2011[57]$
\end{tabular} \\
\hline 20 & Vilnius Lithuania & houses & Pyroglyphidae, & $\begin{array}{l}\text { Dermatophagoides } \\
\text { pteronyssinus, D. farina }\end{array}$ & $\begin{array}{l}\text { Dautartiene. } \\
\text { A. }[58]\end{array}$ \\
\hline
\end{tabular}

